Administrative Issues Journal: Connecting Education, Practice, and Research, Winter 2018, Vol. 8, No. 2: 94-105. DOI: 10.5929/2019.1.14.7

\title{
MACC curriculum and CPA exam passage rates: An exploratory study
}

\author{
Evan M. Shough, Ph.D. \\ Oklahoma City University \\ Beth Stetson, Ph.D., J.D., C.P.A. \\ University of Oklahoma \\ Aubree L. Walton, J.D., C.P.A. \\ Cameron University \\ Kaimee Tankersley, J.D., C.P.A. \\ University of Oklahoma
}

\begin{abstract}
The growing popularity of Master of Accounting programs can be attributed to multiple factors, but the states' adoption of the 150-credit hour educational prerequisite for Certified Public Accountant licensure was clearly influential in stimulating enrollment growth. Despite the growth and importance of Master of Accounting programs, comparative data of program prerequisites and curriculum is scarce. Equally limited are empirical analyses of the effects of graduate curriculum upon CPA Exam passage rates. To address the paucity of information, we examined the program prerequisites and curriculum of 283 Master of Accounting programs, all of which are based in the United States and accredited by the Association to Advance Collegiate Schools of Business. This exploratory study examines (a) commonalities and differences among Master of Accounting program curriculum, (b) relationships between university resource levels and CPA Exam passage rates, and (c) whether programs with a flexible curriculum, providing greater student customization of elective coursework, report higher CPA Exam passage rates.
\end{abstract}

Keywords: Graduate Accounting Curriculum, CPA Exam Passage Rates, 150-Hour CPA Exam Requirement, Accounting Education, Quantitative

\section{Introduction}

The growing popularity of Master of Accounting (MACC) programs can be attributed to multiple factors, but states' adoption of the 150-credit hour prerequisite for Certified Public Accountant (CPA) licensure was influential in stimulating graduate enrollment growth (Boone \& Coe, 2002; Nelson, Vendrzyk, Quirin, \& Kovar, 2008). Despite the growth and importance of MACC programs, comparative data of program prerequisites and curricula is scarce. And, very little research has been conducted on the relationship between MACC curriculum and CPA Exam passage rates. To address the paucity of information, we analyzed programmatic requirements and curriculum design for 283 programs, all of which are based in the United States and accredited by the Association to Advance Collegiate Schools of Business (AACSB), to explore how graduates' CPA Exam passage rates correlate with gradations in student customization of MACC elective courses, as well as, with university resource levels.

Background of the Present Study

SHOUGH, STETSON, WALTON, \& TANKERSLEY / DOI: 10.5929/2019.1.14.7 


\section{Historical Development of the 150-Hour Educational Requirement}

The American Institute of Certified Public Accountants (AICPA) has a long history of promoting graduate education as a prerequisite to obtaining accounting licensure (AICPA, 1968; AICPA, 1969; AICPA, 1973; AICPA, 1988; Roy \& MacNeill, 1967). As early as 1937, the American Institute of Accountants (AIA), the AICPA's predecessor, identified the ideal accounting education as constituting a four-year undergraduate liberal arts program, followed by accounting-intensive studies at the graduate level (Carey, 1970).

Van Wyhe (2007a, 2007b) and Langenderfer (1987) provided extensive discussion of the history of accounting education, noting that support for graduate training was motivated, in part, by a desire to firmly establish the field of accounting as a highly skilled and respected profession, akin to medicine and law. Though the academy, practitioners, legislators, and accreditors demonstrated a cautious, even resistant, response to the call for additional educational prerequisites to licensure, the AICPA's vision consistently advocated for postgraduate educational requirements. Starting in the early 1950s and continuing through the 1980s, numerous committees and task forces studied the issue of accounting education, providing recommendations on the optimal educational model for properly preparing the next generation of accounting professionals, eventually spurring the 150-hour state licensing prerequisite. For example, the 1952 Commission on Standards of Education and Experience, also called the Perry Commission, was an independent commission that recommended enhanced higher education preparation for accounting professionals. The AICPA responded to the Perry Commission report by recommending swift revision of CPA licensing rules, to require completion of postgraduate work devoted specifically to the study of accounting and business (Langenderfer, 1987; Van Wyhe, 2007a, 2007b).

Over the next three decades, similar recommendations emerged from independent task forces, AICPAcoordinated groups, and the AICPA, itself. Although the AICPA's educational reform efforts received considerable resistance from practitioners and academia, the Institute persisted in its advocacy for an extenuated educational experience. However, the AICPA's language gradually shifted away from its initial focus on graduate training. In 1969, the AICPA council passed a resolution stating that "five years" of collegiate study was necessary. By 1978, the AICPA changed its description from the "five year" educational experience to the "150-credit hour" requirement. At this point, the AICPA still envisioned the 150-hours would include some graduate-level studies. In 1988, through a by-law amendment, the AICPA played a key role in motivating all 50 states to implement the 150-credit hour prerequisite for licensure. The by-law amendment stated that, as of the year 2000, a person must have completed 150-credit hours to qualify for AICPA membership. Yet, by this point, the 150-hour rule did not require any graduate level credit (Langenderfer, 1987; Van Wyhe, 2007a, 2007b).

The Pathway Commission's July 2012 report represents the most recent collaborative attention to accounting education reform. The Pathways Commission's feedback mirrored the efforts of previous groups in that it identified modern factors impacting accounting education, recommended broad strategic goals for accounting education, yet it did not venture into specific, tangible detail regarding curriculum (Behn et al., 2012). The Pathway Commission's recommendations have, however, motivated discussions about accounting curriculum (Lawson et al., 2014; Lawson et al., 2015; Spraakman, O'Grady, Askarany, \& Akroyd, 2015; Wygal \& Stout, 2015).

\section{Impact of the 150-Hour Rule}

In 1984, Florida became the first state to implement the 150-credit hour educational prerequisite to taking the CPA Exam (Cumming \& Rankin, 1999). Now, all United States jurisdictions, except the US Virgin Islands, require 150-credit hours to obtain a CPA license (AICPA, 2018).

SHOUGH, STETSON, WALTON, \& TANKERSLEY / DOI: 10.5929/2019.1.14.7 
Following state adoption of the new 150-hour requirement, a significant amount of research focused on how the enhanced educational requirements impacted the supply of accounting majors and graduates, student interest in licensure, and CPA Exam passage rates. Although initial studies reported a decline in accounting majors, accounting graduates, and CPA Exam candidates (Allen \& Woodward, 2006), long-term data reveal a rebound in all three areas (Gramling \& Rosman, 2009). The AICPA's annual study on trends in supply and demand of accounting graduates' reports that undergraduate accounting enrollment dropped from 134,775 students in 2000-2001 to 133,435 students in 2001-2002 (AICPA, 2017). However, undergraduate enrollment has steadily increased each subsequent year to a high of 216,482 undergraduate students reported for the 2015-2016 academic year (AICPA, 2017).

Boone and Coe (2002) found that states with the 150-hour rule reported subsequent growth in MACC graduates. The AICPA data shows that MACC enrollment increased from 10,375 students in 2000-2001 to a high of 39,641 in 2014-2015 (AICPA, 2017). Although graduate enrollment continues to be high, the AICPA reported a slight dip in graduate enrollment following the 2014-2015 academic year (AICPA, 2017).

In addition to tracking the supply of graduates, scholarly work has examined whether the 150-hour requirement improved CPA Exam passage rates and professional preparation. Several studies found that students satisfying the 150-hour rule experienced a significant improvement in CPA Exam scores (Boone, Legoria, Seifert, \& Stammerjohan, 2006; Colbert \& Murray, 1998; Cumming \& Rankin, 1999; Jackson, 2006; Barilla, Jackson, \& Mooney, 2008; Raghunandan, Read, \& Brown, 2003; Read, Raghunandan, \& Brown, 2001). In addition to 150 hours of college preparation, factors such as accreditation, advanced degrees, and programmatic selectivity in student admission have been examined for their relationships with CPA Exam passage rates. Candidates with advanced degrees and those from selective schools tend to produce higher pass rates (Boone, Legoria, Seifert, \& Stammerjohan, 2006; Grant, Ciccotello, \& Dickie, 2002). The findings related to the impact of accreditation have been inconsistent. Jackson and Mooney (2008) found that CPA Exam passage rates improve when students attend a program with AACSB accounting-specific accreditation; whereas AACSB, business-only accreditation does not improve the success of first-time candidates. Whereas Grant, Ciccotello, and Dickie (2002) found a strong relationship between AACSB accreditation and CPA Exam passage rates, Boone, Leogira, Seifert, and Stammerjohan (2006) only reported weak associations.

Inconsistent findings have also been reported on the impact of graduate coursework on improved CPA scores. Some report a significantly positive impact (Sanders, 1972; Titard \& Russell, 1989; Barilla, Jackson, \& Mooney, 2008), while others found that graduate work did not improve performance on the CPA Exam (Reilly \& Stettler, 1972).

\section{Rationale and Research Questions}

Acknowledging that the 150-hour rule has become a permanent academic requirement for licensure, Gramling and Rosman (2013) recommended that future research examine the relationship between a student's path for satisfying the 150-hour requirement and success in both licensure and professional growth. Candidates may satisfy the 150-hour rule via multiple educational paths that include 150-hours of undergraduate education or a mixture of undergraduate and graduate work. Most undergraduate accounting programs provide a student with 120-130 credit hours, leaving students approximately 20 to 30 hours short of meeting the 150-credit hour requirement (Johnson, Reidy, Droll, \& LeMon, 2012). Although the 150-credit hour requirement does not require completion of a graduate degree, many students satisfy the credit hour gap by completing a MACC. Donelan and Philipich (2002) surveyed CPA candidates from four paths that satisfy the 150-hour requirement (undergraduate-only, MACC, MBA with an accounting concentration, and other graduate studies) to determine satisfaction with educational 
preparation. CPA candidates from MACC programs reported greater satisfaction than the other cohorts in terms of academic preparedness in accounting skills, as well as for a majority of the survey's items related to general skills and information technology skills (Donelan \& Philipich, 2002).

Although a considerable amount of scholarly activity has focused on the impact of the 150-hour rule on accounting enrollments, the number of CPA Exam test takers, and the CPA Exam passage rates, scant attention has been given to the role of MACC programs within the 150-hour regime. The purpose of this paper is to provide data for accounting employers, students, educators, and other interested parties regarding the curricula of AACSB-accredited MACC programs and their impact on CPA Exam passage rates. Towards this end, the following research questions were posited:

Research Question 1: What are the commonalities and differences among MACC program prerequisites, total program hours, and required courses for programs at AACSB-accredited programs?

Research Question 2: Does the level of university resources impact CPA Exam passage rates?

Research Question 3: Does the level of student customization of MACC program electives improve CPA Exam passage rates?

\section{Collection and Organization of Data}

From July 2015 through February 2016, we examined the websites of all AACSB accredited schools and determined that 292 such schools offer MACC programs. For these schools, we gathered information regarding their program's required courses, prerequisite courses, total credit hour requirements, and other data. Each program's website was unique. Some program websites identify all available program courses, while the majority identify course names for required courses and summarize the number of electives required for degree completion. We narrowed our data set to 283 schools to ensure data completeness in the quantitative analysis.

\section{Classification of School}

We categorized each school with a MACC program into high, medium, or low resource availability, which we defined by reference to The Carnegie Classification of Institutions of Higher Education (Carnegie). Carnegie is "the leading framework for recognizing and describing institutional diversity in U.S. higher education for the past four and a half decades" (The Carnegie Classification of Institutions of Higher Education [CCIHE], 2018a). We searched our list of 283 schools by name and designated programs as R1, $\mathrm{R} 2$, or R3 schools. Carnegie's "R" classification is for doctoral universities (CCIHE, 2018b). R1 refers to a school producing "highest research activity," R2 refers to a school producing "higher research activity" and R3 refers to a school with "moderate research activity" (CCIHE, 2018b). Schools within the same classification tend to have similar program offerings and resources.

Whereas high resource schools tend to be larger institutions with more resources, they may be able to attract better students, have larger faculties, and provide better facilities. Higher resource schools are more likely to have greater flexibility within the curriculum due to both greater resources and a larger student population from which to draw enrollment. Low resource schools may be more constrained in implementing innovative, flexible or customized coursework. We argue that resource availability impacts accounting curriculum choices, which subsequently impacts student learning and CPA Exam preparation.

In our paper, R1 represents High Resource Schools, R2 represents Medium Resource Schools, and R3 represents Low Resources Schools. Schools listed by Carnegie as Master's Colleges and Universities were 
also included as Low Resources Schools. The "resource" variable serves as a proxy for institutional differences in faculty size, student ability, funding, and reputation. When a Master's degree is the highest level of degree offered by an Accounting program, the program typically absorbs resource constraints including low faculty size and constrained financial support, with attendant limitations on curricular flexibility and customization. The curricular flexibility of R3 Ph.D. granting schools is similarly limited when compared to R1 and R2 schools. The enrollment of R3 schools may be higher than Master's Colleges and Universities but is often lower than enrollment at R1 and R2 schools. For example, the average (median) number of first time CPA Candidates for R1 schools is 198(168), but only 96(62) for R3 schools. Although the nature of curricular constraints may vary somewhat between R3 Ph.D. granting schools and Master's Colleges and Universities, the consequential limitations on program offerings are the same.

\section{Classification of Courses}

We categorized the courses, whether at the graduate or undergraduate level, into seven areas: auditing, cost accounting ("cost"), ethics, financial accounting ("financial"), governmental and nonprofit accounting ("governmental"), law, and tax accounting ("tax"). In our data, we did not include the introductory accounting courses (the two to three sophomore level accounting courses a student is first exposed to) because all business students are required to take these classes. We instead focused our data on information related to upper-division undergraduate courses and graduate courses. In general, courses were classified as accounting courses if they had an accounting prefix in the course catalog. However, this classification method did not work well for required courses in ethics and law. Institutions utilize varied approaches for cataloging ethics and law courses, with some assigning accounting prefixes and others utilizing a non-accounting prefix. To ensure our data set captured required coursework mapped to CPA Exam content, calculations of "required accounting hours" includes required coursework in ethics and law, regardless of institutional prefix selections. Finally, in instances where a course could have been taken at either the graduate or undergraduate level, we assigned graduate course classification. Quarter credit hours were counted as two-thirds of a credit hour.

\section{Results}

\section{Research Question 1: What are the Commonalities and Differences Among MACC Program Prerequisites, Total Program Hours, and Required Courses for Programs at AACSB-Accredited Programs?}

The data collected focused on program characteristics, program prerequisites, total program hours, and required courses (if any) making up those program hours.

As seen in Table 1, to enter a MACC program, a student is not required to have an accounting or even a business degree. Only $6.7 \%$ of schools specifically required an accounting degree for entry into their program. An additional $9.2 \%$ of schools required at least an undergraduate degree in a business school discipline. Therefore, about $84 \%$ of the programs ( 238 of 283 ) did not require a business education for entry into a graduate accounting program. R1 schools are more likely to require an accounting degree $(9.6 \%)$ or business degree $(22.9 \%)$ to be accepted into the graduate program, while R2 and R3 schools are more likely to admit non-business students directly into their programs. 
Table 1

Program Characteristics of MACC Programs

\begin{tabular}{|l|c|c|c|c|c|c|}
\hline $\begin{array}{l}\text { Resource } \\
\text { Level }\end{array}$ & $\begin{array}{c}\text { Total } \\
\text { Programs }\end{array}$ & $\begin{array}{c}\text { Accounting } \\
\text { Degree } \\
\text { Required }\end{array}$ & $\begin{array}{c}\text { Accounting } \\
\text { or Business } \\
\text { Degree } \\
\text { Required }\end{array}$ & $\begin{array}{c}\text { Total } \\
\text { Accounting } \\
\text { Prerequisite } \\
\text { Hours } \\
\text { (Median) }\end{array}$ & $\begin{array}{c}\text { Taxation } \\
\text { Specialty } \\
\text { Offered }\end{array}$ & $\begin{array}{c}\text { Other } \\
\text { Specialty } \\
\text { Offered }\end{array}$ \\
\hline R1 Schools & 83 & $9.6 \%$ & $22.9 \%$ & 16.50 & $44.6 \%$ & $22.9 \%$ \\
\hline R2 Schools & 69 & $5.8 \%$ & $13.0 \%$ & 18.00 & $37.7 \%$ & $20.3 \%$ \\
\hline R3 Schools & 131 & $5.3 \%$ & $13.0 \%$ & 18.00 & $23.7 \%$ & $9.9 \%$ \\
\hline Total & 283 & $6.7 \%$ & $15.9 \%$ & 18.00 & $33.2 \%$ & $16.3 \%$ \\
\hline
\end{tabular}

Slightly more than one-third (103 of 283) of the schools offered at least one specialty track. R1 and R2 schools were significantly more likely to offer specialty tracks, both tax and other, than R3 schools. Because specialty tracks generally require larger programs and more faculty resources, this is not surprising.

Although an undergraduate accounting or business degree is generally not required to enter a MACC program, considerable prerequisite coursework is usually required, either directly as an admission requirement, or indirectly as a requirement to take the courses constituting the program. Of the 238 programs without a business undergraduate degree requirement, 185 required, at the minimum, twelve credit hours of undergraduate business courses. The remaining programs generally required a significant number of undergraduate business courses. Programs generally required 15-18 hours (five to six classes) of undergraduate accounting courses, typically comprised of two financial courses (i.e., Intermediate Accounting I and Intermediate Accounting II), one auditing course, one tax course, and one cost course. An undergraduate governmental course was rarely required. Prerequisites are similar across R1, R2, and R3 schools.

Table 2

MACC Admission Requirements: Required Prerequisite Coursework

\begin{tabular}{|l|l|r|r|r|r|r|r|r|}
\hline Resource Level & Courses Required & Financial & Auditing & Tax & Cost & Gov't & Ethics & Law \\
\hline \multirow{3}{*}{ R1 Schools } & $\mathbf{1}$ & $6.0 \%$ & $71.1 \%$ & $69.9 \%$ & $74.7 \%$ & $0.0 \%$ & $24.1 \%$ & $49.4 \%$ \\
\cline { 2 - 8 } & $\mathbf{2}$ or more & $83.1 \%$ & $2.4 \%$ & $7.2 \%$ & $0.0 \%$ & $0.0 \%$ & $0.0 \%$ & $0.0 \%$ \\
\cline { 2 - 8 } & Not Required & $10.8 \%$ & $26.5 \%$ & $22.9 \%$ & $25.3 \%$ & $100.0 \%$ & $75.9 \%$ & $50.6 \%$ \\
\hline \multirow{3}{*}{ R2 Schools } & $\mathbf{1}$ & $0.0 \%$ & $76.8 \%$ & $73.9 \%$ & $73.9 \%$ & $7.2 \%$ & $14.5 \%$ & $52.2 \%$ \\
\cline { 2 - 9 } & $\mathbf{2}$ or more & $91.3 \%$ & $0.0 \%$ & $4.3 \%$ & $1.4 \%$ & $0.0 \%$ & $0.0 \%$ & $10.1 \%$ \\
\cline { 2 - 9 } & Not Required & $8.7 \%$ & $23.2 \%$ & $21.7 \%$ & $24.6 \%$ & $92.8 \%$ & $85.5 \%$ & $37.7 \%$ \\
\hline \multirow{3}{*}{ R3 Schools } & $\mathbf{1}$ & $2.3 \%$ & $72.5 \%$ & $74.0 \%$ & $73.3 \%$ & $1.5 \%$ & $20.6 \%$ & $41.2 \%$ \\
\cline { 2 - 9 } & $\mathbf{2}$ or more & $87.0 \%$ & $1.5 \%$ & $8.4 \%$ & $2.3 \%$ & $0.0 \%$ & $1.5 \%$ & $6.1 \%$ \\
\cline { 2 - 9 } & Not Required & $10.7 \%$ & $26.0 \%$ & $17.6 \%$ & $24.4 \%$ & $98.5 \%$ & $77.9 \%$ & $52.7 \%$ \\
\hline
\end{tabular}

In sum, a student with a liberal arts degree would typically need to complete 12 hours of undergraduate business (non-accounting) courses and 15-18 hours of undergraduate accounting courses. However, a 
student with a finance degree who completed Intermediate Accounting I and II as an undergraduate would typically need to complete only nine to twelve hours of undergraduate accounting courses.

Table 3

Total Program Credit Hour Requirements

\begin{tabular}{|l|c|c|c|}
\hline $\begin{array}{l}\text { Number of Schools }= \\
\mathbf{2 8 3}\end{array}$ & $\begin{array}{c}\text { Total Graduate } \\
\text { Hours }\end{array}$ & $\begin{array}{c}\text { Total Graduate Accounting } \\
\text { Hours }\end{array}$ & $\begin{array}{c}\text { Total Graduate } \\
\text { Accounting Hours - } \\
\text { Specific Courses }\end{array}$ \\
\hline Median & 30.00 & 21.00 & 15.00 \\
\hline Mean & 31.06 & 22.60 & 14.40 \\
\hline
\end{tabular}

MACC programs generally required 30 hours of graduate coursework (217 of 283 schools). Only five schools required less than 30 hours (ranging from 21 to 29.3 hours), and 61 schools required more than 30 hours (ranging from 31 to 54 hours). The 30-hour graduate program generally required fifteen hours of accounting courses, six hours of accounting electives, and nine credit hours of non-accounting courses.

Table 4

Specific Graduate Course Requirements

\begin{tabular}{|c|c|c|c|c|c|c|c|c|}
\hline $\begin{array}{c}\text { Resource } \\
\text { Level }\end{array}$ & $\begin{array}{l}\text { Courses } \\
\text { Required }\end{array}$ & Financial & Auditing & Taxation & Cost & Gov't & Ethics & Law \\
\hline \multirow{3}{*}{$\begin{array}{c}\text { R1 } \\
\text { Schools }\end{array}$} & 1 & $36.1 \%$ & $51.8 \%$ & $53.0 \%$ & $33.7 \%$ & $13.3 \%$ & $36.1 \%$ & $37.3 \%$ \\
\hline & 2 or more & $55.4 \%$ & $30.1 \%$ & $24.1 \%$ & $2.4 \%$ & $0.0 \%$ & $3.6 \%$ & $2.4 \%$ \\
\hline & $\begin{array}{l}\text { Not } \\
\text { Required }\end{array}$ & $8.4 \%$ & $18.1 \%$ & $22.9 \%$ & $63.9 \%$ & $86.7 \%$ & $60.2 \%$ & $60.2 \%$ \\
\hline \multirow{4}{*}{$\begin{array}{c}\text { R2 } \\
\text { Schools }\end{array}$} & & & & & & & & \\
\hline & 1 & $30.4 \%$ & $47.8 \%$ & $52.2 \%$ & $44.9 \%$ & $20.3 \%$ & $27.5 \%$ & $26.1 \%$ \\
\hline & 2 or more & $50.7 \%$ & $17.4 \%$ & $13.0 \%$ & $0.0 \%$ & $0.0 \%$ & $0.0 \%$ & $0.0 \%$ \\
\hline & $\begin{array}{l}\text { Not } \\
\text { Required }\end{array}$ & $18.8 \%$ & $34.8 \%$ & $34.8 \%$ & $55.1 \%$ & $79.7 \%$ & $72.5 \%$ & $73.9 \%$ \\
\hline & & & & & & & & \\
\hline \multirow{3}{*}{$\begin{array}{c}\text { R3 } \\
\text { Schools }\end{array}$} & 1 & $34.4 \%$ & $60.3 \%$ & $61.1 \%$ & $41.2 \%$ & $29.8 \%$ & $43.5 \%$ & $28.2 \%$ \\
\hline & 2 or more & $55.0 \%$ & $19.8 \%$ & $16.0 \%$ & $3.1 \%$ & $1.5 \%$ & $5.3 \%$ & $0.8 \%$ \\
\hline & $\begin{array}{l}\text { Not } \\
\text { Required }\end{array}$ & $10.7 \%$ & $19.8 \%$ & $22.9 \%$ & $55.7 \%$ & $68.7 \%$ & $51.1 \%$ & $71.0 \%$ \\
\hline
\end{tabular}

Although not requiring a course is not the same as not offering a course, course requirements lend insight into the emphasis of the different programs; that is, programs presumably require specific graduate coursework in functional areas they perceive as important.

Programs appear to perceive financial as the most important functional area, with over $50 \%$ of schools requiring two or more graduate financial courses and over $80 \%$ requiring at least one such course. Programs appear to also perceive auditing and tax as important functional areas, with the majority of schools requiring at least one graduate course in each of these areas. Interestingly, R1 schools were significantly more likely than R2 and R3 schools to require two or more graduate courses in either auditing, or tax, or both. The graduate course requirements for financial, auditing, and tax courses somewhat mirror the undergraduate course requirements in these areas, providing further evidence of their 
perceived importance. R1 schools were significantly less likely than R2 and R3 schools to require graduate cost and governmental courses. R1 and R3 schools were significantly more likely than R2 schools to require a graduate ethics course. R1 schools were significantly more likely than R2 and R3 schools to require a graduate law course.

\section{Research Question 2: Does the Level of University Resources Impact CPA Exam Passage Rates?}

Does curriculum choice impact learning outcomes for the program? Ideally, we would study direct learning outcomes, job placement statistics and other potentially interesting outcomes for graduating students. Practically, we have access to CPA Exam scores and overall passage rates by school, for purposes of analyzing whether MACC curriculum impacts CPA Exam test outcomes. For our analysis, we averaged the Overall passage rate and Average Test Scores for all CPA Exam sections taken by first-time test takers from a school during 2015 and 2016. We looked at average CPA Exam test scores and overall passage rates as they relate to two dimensions. The first discussed here, is the Resource Level of the schools.

Table 5 shows that a school's Resource Level makes a significant difference in program graduates' CPA Exam Passage Rates and Average Scores.

Table 5

Impact of University Resource Level on CPA Exam Passage Rates

\begin{tabular}{|l|c|l|l|l|l|l|}
\hline $\begin{array}{c}\text { Resource } \\
\text { Level }\end{array}$ & $\begin{array}{c}\text { Passage } \\
\text { Rate }\end{array}$ & $\begin{array}{c}\text { High to X } \\
\text { P Value }\end{array}$ & $\begin{array}{c}\text { Medium to } \\
\text { X P Value }\end{array}$ & $\begin{array}{c}\text { Average } \\
\text { Score }\end{array}$ & $\begin{array}{c}\text { High to X } \\
\text { P Value }\end{array}$ & $\begin{array}{c}\text { Medium to } \\
\text { X P Value }\end{array}$ \\
\hline High & $63.5663 \%$ & & & $75.8193 \%$ & & \\
\hline Medium & $56.8703 \%$ & 0.0004 & & $73.5036 \%$ & 0.0007 & \\
\hline Low & $50.5377 \%$ & $<.0001$ & 0.0002 & $71.3535 \%$ & $<.0001$ & 0.0006 \\
\hline
\end{tabular}

Research Question 3: Does the Level of Student Customization of MACC Program Electives Improve CPA Exam Passage Rates?

The second dimension we analyzed is what we called customization. Customization is the flexibility within program offerings. MACC programs with Low Customization have the highest number of required courses to total program hours and offer students very few elective hours. High Customization programs offer the lowest number of required courses to total program hours and instead allow students many elective choices. To create this variable, we identified the required number of courses in each program as a percentage of the total number of courses in the program. Programs were then classified as High, Medium, or Low Customization based on which third of the distribution they found themselves in this variable.

Table 6

Customization of MACC Coursework and Relationship to CPA Exam Passage Rates

\begin{tabular}{|l|c|c|c|}
\hline \multicolumn{1}{|c|}{ Resource Level } & $\begin{array}{c}\text { High Elective } \\
\text { Customization }\end{array}$ & $\begin{array}{c}\text { Medium Elective } \\
\text { Customization }\end{array}$ & $\begin{array}{c}\text { Low Elective } \\
\text { Customization }\end{array}$ \\
\hline High & $67.24 \%$ & $61.09 \%$ & $61.71 \%$ \\
\hline Medium & $56.28 \%$ & $57.73 \%$ & $57.39 \%$ \\
\hline Low & $53.14 \%$ & $48.94 \%$ & $48.98 \%$ \\
\hline
\end{tabular}


Table 7

T-test Comparisons of CPA Exam Passage Rates across Customization Categories

\begin{tabular}{|l|l|l|}
\hline \multicolumn{1}{|c|}{ T-test } & High-Medium & High-Low \\
\hline R1 & 0.033 & 0.026 \\
\hline R2 & 0.338 & 0.369 \\
\hline R3 & 0.055 & 0.034 \\
\hline
\end{tabular}

Table 8

Customization of MACC Coursework and Relationship to Average Test Scores

\begin{tabular}{|l|c|c|c|}
\hline \multicolumn{1}{|c|}{ Resource Level } & $\begin{array}{c}\text { High Elective } \\
\text { Customization }\end{array}$ & $\begin{array}{c}\text { Medium Elective } \\
\text { Customization }\end{array}$ & $\begin{array}{c}\text { Low Elective } \\
\text { Customization }\end{array}$ \\
\hline High & $77.02 \%$ & $75.06 \%$ & $75.19 \%$ \\
\hline Medium & $73.37 \%$ & $73.87 \%$ & $73.47 \%$ \\
\hline Low & $72.27 \%$ & $70.89 \%$ & $70.75 \%$ \\
\hline
\end{tabular}

Table 9

T-test Comparisons of CPA Average Test Scores across Customization Categories

\begin{tabular}{|l|l|l|}
\hline \multicolumn{1}{|c|}{ T-test } & \multicolumn{1}{c|}{ High-Medium } & High-Low \\
\hline R1 & 0.054 & 0.039 \\
\hline R2 & 0.348 & 0.467 \\
\hline R3 & 0.075 & 0.033 \\
\hline
\end{tabular}

We found that for High Resource schools more customization in the MACC curriculum led to higher passage rates and higher average scores on the CPA Exam. This result also holds for Low Resource schools, which tend to be smaller schools. We found no effect for the Medium Resource schools.

We cut the customization data into two categories (High and Low), and the results were quantitatively similar. We also tried four categories and, again, the results were quantitatively similar. We used alternative definitions of customization, using total MACC prerequisite requirements and hours, and observed quantitatively similar results. We defined Resource Level using the size of the programs (based on the average number of first-time students at each school sitting for the CPA exam in 2015 and 2016). The results for the High Resource schools were similar but Low Resource schools were different, leading us to believe that our primary classification was capturing other factors, besides program size, that impact student performance. The additional factors, which may include the academic ability and financial resources, were not necessarily correlated with program size.

\section{Implications}

Despite a paucity of input regarding MACC program curriculum, our study indicates a relatively high degree of curriculum consistency. Although few programs require an undergraduate accounting or even undergraduate business (non-accounting) degree, students generally must complete 15-18 hours of undergraduate accounting coursework and approximately twelve hours of undergraduate business (nonaccounting) coursework, either before or concurrent with the program. Most programs require approximately 30 hours of graduate coursework, generally composed of one or more financial courses, and at least one audit and one tax course (but not a cost or a governmental course). Programs apparently view financial as the most important course, with over $50 \%$ of programs requiring two or more such courses. School research intensity does appear to impact curriculum. For example, R1 "highest research 
activity" schools tend to require more audit, tax, ethics, and law courses, but fewer cost and governmental courses.

Our results indicate that higher resource levels are correlated with better CPA Exam performance. Our results also indicate that for High Resource and Low Resource (but not Medium Resource) schools, greater curriculum leeway in elective customization is correlated with better CPA Exam performance. The High Resource schools may have the ability to offer more electives in their programs, yet the reason for similar results in Low Resource schools results is less clear. Low Resource schools in our classification tend to be smaller schools. It may be that smaller schools that offer more customization in their programs are able to attract better students.

This may be the first study of MACC Curriculum, and it is the first we are aware of that shows a potential relationship between curriculum and CPA Exam performance. We believe that more research needs to be conducted in this area to improve and adapt the curriculum in the MACC programs to more effectively train the next generation of our profession.

\section{References}

Allen, A., \& Woodland, A. (2006). The 150-hour requirement and the number of CPA exam candidates, pass rates, and the number passing. Issues in Accounting Education, 21, 173-193.

American Institute of Certified Public Accountants. (1968). Academic preparation for professional accounting careers. New York, NY: AICPA.

American Institute of Certified Public Accountants. (1969). Report of the Committee on Education and Experience Requirements for CPAs. New York, NY: AICPA.

American Institute of Certified Public Accountants. (1973). AICPA endorses professional schools of accounting. Journal of Accountancy, 20-21.

American Institute of Certified Public Accountants. (1988). Education requirements for entry into the accounting profession ( $2^{\text {nd }}$ ed.) New York, NY: AICPA.

American Institute of Certified Public Accountants. (2017). 2017 trends in the supply of accounting graduates and the demand for public accounting. Retrieved from https://www.aicpa.org/interestareas/accountingeducation/newsandpublications/downloadable documents/2017-trends-report.pdf

American Institute of Certified Public Accountants. (2018, June). 150 hour requirement for obtaining a CPA license. Retrieved from https:// www.aicpa.org/becomeacpa/licensure/requirements.html\#states

Barilla, A. G., Jackson, R. E., \& Mooney, J. L. (2008). The CPA exam as a postcurriculum accreditation assessment. Journal of Education for Business, 83, 270-274.

Behn, B. K., Ezzell, W. F., Murphy, L. A., Rayburn, J. D., Smith, M. T., \& Strawser, J. R. (2012). The Pathways Commission on Accounting Higher Education: Charting a national strategy for the next generation of accountants. Issues in Accounting Education, 27(3), 595-600.

Boone, J. P., \& Coe, T. L. (2002). The 150-hour requirement and changes in the supply of accounting undergraduates: Evidence from a quasi-experiment. Issues in Accounting Education, 17, 253-268.

SHOUGH, STETSON, WALTON, \& TANKERSLEY / DOI: 10.5929/2019.1.14.7 
Boone, J., Legoria, J., Seifert, D. L., \& Stammerjohan, W. W. (2006). The associations among accounting program attributes, 150-hour status, and CPA exam pass rates. Journal of Accounting Education, 24, 202-215.

Carey, J. L. (1970). The rise of the accounting profession: To responsibility and authority, 1937-1969. New York, NY: AICPA.

Carnegie Classification of Institutions of Higher Education. (2018a). About the Carnegie Classification. Retrieved from http://carnegieclassifications.iu.edu/

Carnegie Classification of Institutions of Higher Education. (2018b). Basic classification description. Retrieved from http://carnegieclassifications.iu.edu/classification descriptions/basic.php

Colbert, G., \& Murray, D. (1998). The association between states' education requirements and CPA exam performance. Research in Accounting Regulation, 12, 93-108.

Cumming, J., \& Rankin, L. J. (1999). 150 hours: A look back. Journal of Accountancy, 187(4), 53-58.

Donelan, J. G., \& Philipich, K. L. (2002). Meeting the 150-hour requirement: The impact of curriculum choice on satisfaction. Journal of Accounting Education, 20, 105-121.

Gramling, L. J., \& Rosman, A. J. (2009). The ongoing debate about the impact of the 150-hour education requirement on the supply of certified public accountants. Issues in Accounting Education, 24, 465-479.

Gramling, L. J., \& Rosman, A. J. (2013). The ongoing debate of and direction for future research about the impact of the 150-hour education requirement on the supply of certified public accountants. Issues in Accounting Education, 28(3), 503-512.

Grant, C. T., Ciccotello, C. S., \& Dickie, M. (2002). Barriers to professional entry: how effective is the 150hour rule? Journal of Accounting and Public Policy, 21, 71-93.

Jackson, R. E. (2006). Post-graduate educational requirements and entry into the CPA profession. Journal of Labor Research, 27, 101-114.

Johnson, N., Reidy, L., Droll, M., \& LeMon, R. E. (2012, July). Program requirements for associate's and bachelor's degrees: A national survey. Retrieved from https://completecollege.org/wpcontent/uploads/2017/11/Program-Requirements-A-National-Survey.pdf

Langenderfer, H. Q. (1987). Accounting education's history - a 100-year search for identity. Journal of Accountancy, 163(5), 302-331.

Lawson, R. A., Blocher, E. J., Brewer, P. C., Cokins, G., Sorensen, J. E., Stout, D. E., ... Wouters, M. J. F. (2014). Focusing accounting curricula on students' long-run careers: Recommendations for an integrated competency-based framework for accounting education. Issues in Accounting Education, 29(2), 295-317.

Lawson, R. A., Blocher, E. J., Brewer, P. C., Morris, J. T., Stocks, K. D., Sorensen, J. E., ... Wouters, M. J. F. (2015). Thoughts on competency integration in accounting education. Issues in Accounting Education, 30(3), 149-171.

Nelson, I. T., Vendrzyk, V. P., Quirin, J. J., \& Kovar, S. E. (2008). Trends in accounting student characteristics: Results from a 15-year longitudinal study at FSA schools. Issues in Accounting Education, 23(3), 373-389. 
Raghunandan, K., Read, W. J., \& Brown, C. D. (2003). 150-hour rule: does it improve CPA exam performance? Managerial Auditing Journal, 18, 31-38.

Read, W. J., Raghunandan, K., \& Brown, C. D. (2001). 150-preparation improves CPA exam performance. The CPA Journal, 71, 30-33.

Reilly, F. K., \& Stettler, H. F. (1972). Factors influencing success on the CPA examination. Journal of Accounting Research, 10(2), 308-321.

Roy, R. H. \& MacNeill, J. H. (1967). Horizons for a profession. New York, NY: AICPA.

Sanders, H. P. (1972). Factors in achieving success on the CPA examination. Journal of Accountancy, $134,85-88$.

Spraakman, G., O'Grady, W., Askarany, D., \& Akroyd, C. (2015). Employers' perceptions of information technology competency requirements for management accounting graduates. Accounting Education, 24(5), 403-422.

Titard, P. L., \& Russell, K. A. (1989). Factors affecting CPA examination success. Accounting Horizons, 3(3), 53-59.

Van Wyhe, G. (2007). A history of U.S. higher education in accounting, Part I: Situating accounting within the academy. Issues in Accounting Education, 22(2), 165-181.

Van Wyhe, G. (2007). A history of U.S. higher education in accounting, Part II: reforming accounting within the academy. Issues in Accounting Education, 22(3), 481-501.

Wygal, D. E., \& Stout, D. E. (2015). Shining a light on effective teaching best practices: Survey findings from award-winning accounting educators. Issues in Accounting Education, 30(3), 173-205.

\section{About the Authors}

Evan M. Shough (emshough@okcu.edu) is the Dr. Henry James Freede Professor in Teaching Excellence Chair at Oklahoma City University in Oklahoma City, Oklahoma. Shough serves as Department of Accounting Chair, has been Director of the MSA program for the past five years, and has been a member of OCU's Meinders School of Business for ten years.

Beth Stetson (bstetson@ou.edu) is the Charles C. and Virginia Ann Weddle Professor of Accounting and Associate Professor of Accounting at the University of Oklahoma in Norman, Oklahoma.

Aubree Walton (aubreeh@cameron.edu) is Associate Professor at Cameron University, in Lawton, Oklahoma. She teaches courses in business law, financial accounting, and tax.

Kaimee Tankersley (ktankersley@ou.edu) is a lecturer in the University of Oklahoma Price College of Business, John T. Steed School of Accounting, as well as managing member of Kellis Tankersley, PLLC. 